\title{
Analisis Web Traffic untuk Keamanan Informasi dan Domain Pengunjung di UIN Jakarta
}

\author{
Andrew Fiade \\ Program Studi Teknik Informatika \\ Universitas Islam Negeri Jakarta \\ Tangerang-Indonesia \\ andrew fiade@,uinjkt.ac.id
}

Diterima: 6 Maret 2016. Disetujui: 11 April 2016. Dipublikasikan: Mei 2016

\begin{abstract}
Abstrak - Tantangan big data meliputi proses perolehan, penyimpanan, penelusuran, pembagian, pemindahan, analisis, dan pemvisualan data. Web based menjadi salah satu contoh dari penerapan big data. Saat ini user dari seluruh dunia mengakses web. Banyak informasi yang dapat diambil dalam penggunaan web seperti halaman apa saja yang sering diakses user, waktu akses user yang paling sering, dan kata kunci yang sering digunakan dalam pencarian web untuk mendapatkan domain web yang dituju. Untuk sisi keamanan informasi, dapat diketahui bagaimana cara sebuah halaman web telah di-deface atau telah disisipkan file tertentu oleh user dari luar sehingga user luar dapat mengambil informasi yang sensitif serta apakah web tersebut pernah digunakan untuk mengakses sql injection. Dalam penelitian ini dianalisa domain uinjkt.ac.id yang memiliki sekitar 72 sub domain dan perlu untuk dimonitoring. Metode yang digunakan adalah Rapid Application Development. Dari hasil pengujian didapatkan bahwa subdomain sudah dapat dimonitor dan terdapat beberapa user luar mencoba akses hack ke situs UIN. Kedepannya penelitian ini dapat ditingkatkan untuk alert dan tindakan pencegahan atau pemblokan akses.
\end{abstract}

Kata Kunci: big data; web analysis; sql injection; security.

\section{PENDAHULUAN}

Saat ini perkembangan big data menjadi topik penelitian yang sedang berkembang. Definisi dari big data adalah istilah umum untuk segala kumpulan himpunan data dalam jumlah sangat besar dan kompleks sehingga menjadikannya sukar ditangani kalau hanya memakai manajemen basis data biasa. Tantangan big data meliputi proses perolehan, penyimpanan, penelusuran, pembagian, pemindahan, analisis, dan pemvisualan data [1].

Universitas Islam Negeri (UIN) Jakarta dalam penanganan web diproses oleh Pustipanda. Pustipanda menangani banyak web untuk kepentingan prodi, fakultas, unit, blog dosen, blog mahasiswa. Tercatat ada sekitar 100 lebih sub domain uinjkt.ac.id yang dikelola oleh Pustipanda. Dari beberapa akses, didapatkan informasi beberapa web subdomain uinjkt.ac.id telah disusupi hacker. Dari kisaran 100 lebih sub domain, maka diperlukan satu sistem aplikasi yang dapat monitoring seluruh domain web uinjkt.ac.id. Baik dari segi popularitas web, akses user, maupun monitoring sistem untuk keamanan web.

Dengan informasi tersebut maka penulis mencoba membuat aplikasi yang dapat menerapkan analisa yang ingin didapatkan. Terutama untuk kemanan informasi dan profil user yang mengakses, Percobaan akan diujicobakan ke 10 situs dan diambil data $\log$ dari tiap situs kemudian dianalisa untuk mendapatkan informasi yang dispesifikasikan sebelumnya.

Permasalahan utama yang dihadapi adalah pada bagaimana memantau web yang dimiliki dari keamanan informasi seperti deface dan sql injection terhadap web dan data di web tersebut, akses user seperti asal lokasi user, halaman akses untuk penentuan top halaman yang diakses, dan profile lainnya [2]. Dalam beberapa kasus ada situs yang banyak diakses sehingga membuat web menjadi susah diakses. Dengan mengetahui jumlah user yang mengakses dapat ditentukan kapan waktu yang dibutuhkan untuk web tersebut.[1]

Tujuan dari penelitian adalah untuk memperoleh data yang akurat dan realtime untuk web yang dimiliki, sehingga kemudahan untuk menempatkan kategori halaman atau artikel yang sering diakses. Admin dapat memperoleh bagaimana tingkat kepopuleran web tersebut untuk peningkatan webometric. Serta untuk keamanan informasi dapat memantau ada tidaknya halaman yang aneh (disalah gunakan) dari web tersebut. Adapun manfaat dari penelitian ini yaitu dapat dijadikan rujukan ataupun 
panduan oleh stake holder untuk melihat sejauh mana situs domain uinjkt diakses, situs apa yang sering diakses dan kapan waktu traffic tinggi yang sering diakses, berita apa saja yang sering dibaca oleh user. Sehingga dapat menjadi pedoman dalam mengambil keputusan untuk peningkatan kepopuleran web.

\section{LANDASAN TEORI}

Web analytics adalah pengukuran, pengumpulan, analisis dan pelaporan data internet untuk tujuan pemahaman dan mengoptimalkan penggunaan web. Web analytics bukan hanya sebuah alat untuk mengukur lalu lintas situs web, namun dapat digunakan sebagai alat untuk penelitian bisnis dan riset pasar. Aplikasi analisis web dapat juga membantu perusahaan mengukur hasil kampanye iklan cetak tradisional [3]. Hal ini membantu orang untuk memperkirakan bagaimana lalu lintas ke situs web berubah setelah peluncuran kampanye iklan baru. Web analytics menyediakan data tentang jumlah pengunjung, tampilan halaman dan lain-lain untuk mengukur popularitas situs yang akan membantu untuk melakukan riset pasar. Ada dua kategori analisis web yaitu off-site dan on-site [4].

Off-site web analisis mengacu pada pengukuran dan analisis web yang mencakup pengukuran potensi sebuah situs web penonton (kesempatan), berbagi suara (visibilitas), dan buzz (komentar) yang terjadi di Internet secara keseluruhan. On-site web analytics mengukur perjalanan sekali pengunjung di website yang mencakup driver dan konversi, misalnya halaman arahan yang mendorong orang untuk melakukan pembelian. On-site analisis web mengukur kinerja situs dalam konteks komersial. Data ini biasanya dibandingkan terhadap indikator kinerja kunci kinerja, dan digunakan untuk meningkatkan situs web atau kampanye pemasaran respons penonton [5]

Secara historis, analisis web telah disebut di pengukuran pengunjung situs. Namun dalam beberapa tahun terakhir ini telah kabur, terutama karena vendor yang memproduksi alat-alat yang masuk ke kedua kategori [6]. Dalam penelitian ini peneliti mencoba menerapkan ke studi kasus di uinjkt.ac.id untuk mendapatkan analisa web yang dapat diperoleh dari situs tersebut.

\section{METODOLOGI}

Tempat dan waktu penelitian dalam penelitian ini adalah: Pustipanda (Pusat Pangkalan data dan informasi) UIN Jakarta pada April - Oktober 2015.
Peneliti tergabung dalam tim Pustipanda, sebagai koordinator security dan data center. Aplikasi dan sistem informasi prodi, lembaga, fakultas dikelola oleh Pustipanda. Banyak dari sistem tersebut belum terpantau secara aplikasi. Adapun pengecekan aplikasi dipantau secara manual dicek satu persatu log dari web tersebut. Terjadi kesulitan untuk cek semua aplikasi, sehingga diperlukan satu aplikasi untuk monitoring dan analisa traffic untuk keseluruhan domain aplikasi uinjkt.ac.id

Peneliti sebagai pelaku juga dalam Pustipanda, maka observasi yang dilakukan adalah melihat data subdomain uinjkt.ac.id, melihat track site domain yang telah ter-hack. Kemudian mencari alternatif solusi untuk melihat keseluruhan web dalam satu media, dan dirancang aplikasi yang dibutuhkan. Pada teknik pengumpulan data, peneliti membuat aplikasi yang dapat diakses di jaringan internet dengan alamat 103.229.202.50/log. Untuk menghubungkan antara server dan situs domain uinjkt.ac.id, peneliti menggunakan kode java script ataupun php yang kemudian akan disisipkan di halaman html pada tiap domain $w e b$

Aplikasi memberikan kode javascript untuk uinjkt.ac.id, yaitu:

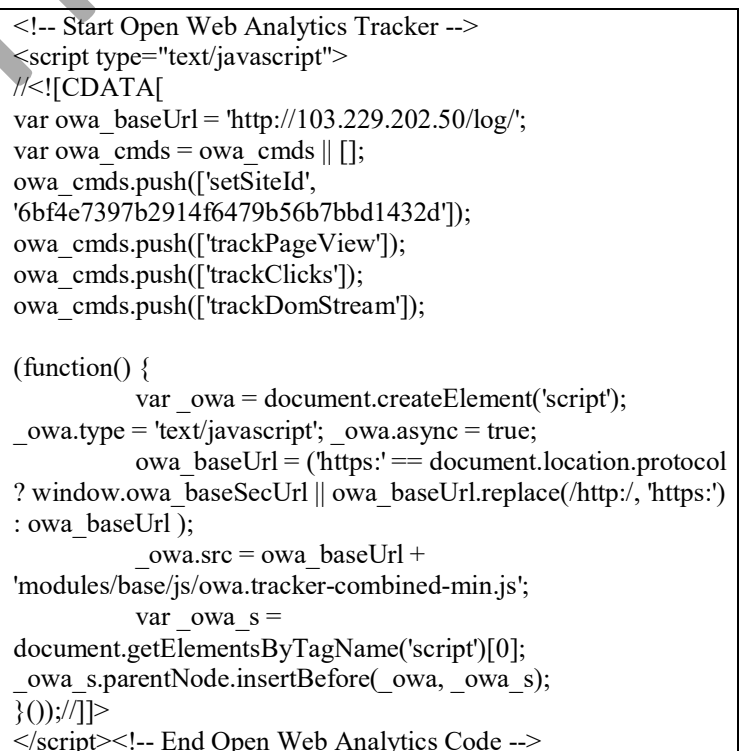

Kode tracking untuk akademik.uinjkt.ac.id yaitu:

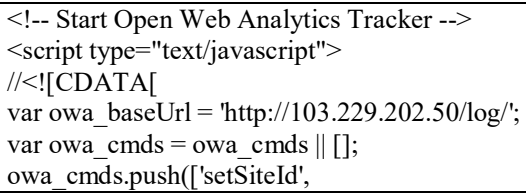




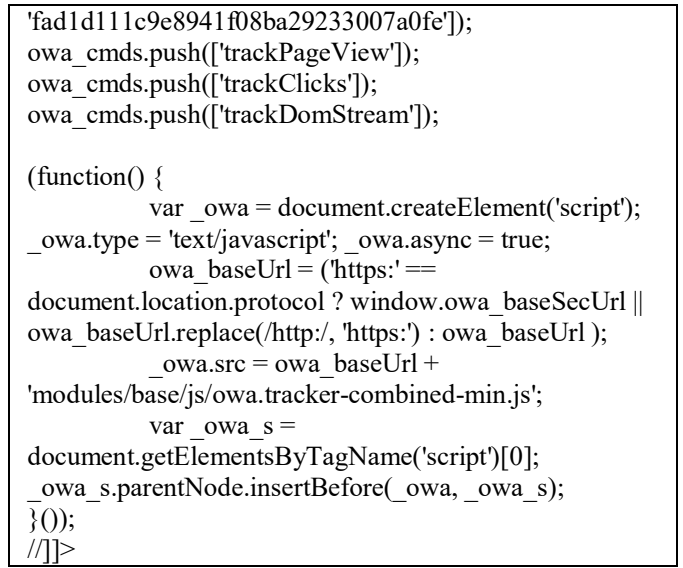

Tracking kode untuk domain spi-blu.uinjkt.ac.id adalah:

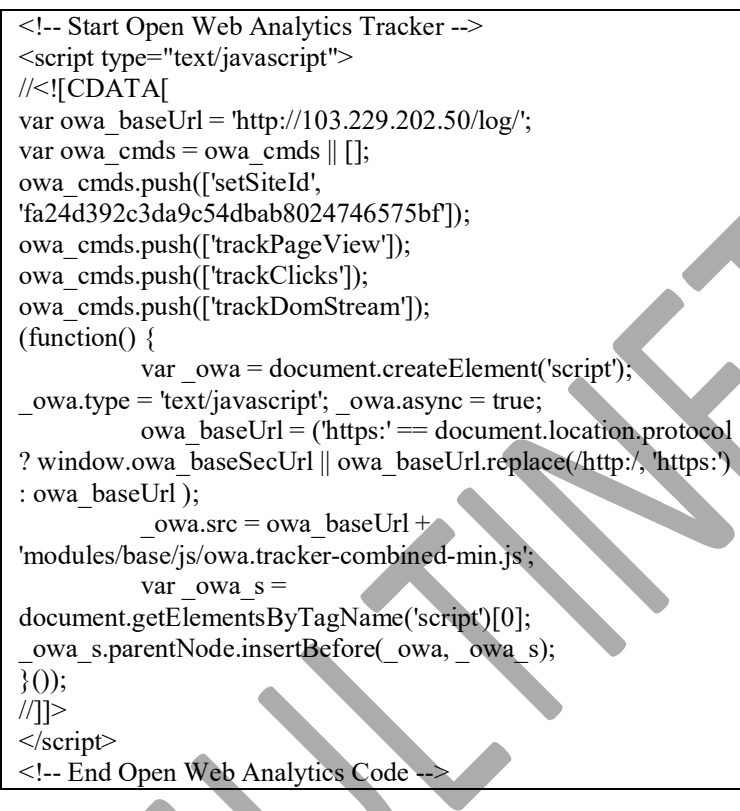

Prosedur pengolahan data dalam aplikasi ini adalah:

- Aplikasi mencatat nama web, seumpama uinjkt.ac.id, selanjutnya aplikasi generate kode tracking dalam bentuk java script.

- Kode java script diletakan di bagian index.html pada web domain yang dituju, dapat di index.html atau di folder template di index.html

- Kode java script diletakan di bagian head. Seperti contoh:
$<$ HTML $>$
$<$ HEAD $>$
Letakan kode java script
$</ \mathrm{HEAD}>$

Dan langkah tersebut berlaku untuk semua web yang akan disertakan untuk dimonitor diaplikasi.

Untuk membedakan antara domain web lainnya yang dikelola oleh aplikasi diberikan id untuk masing masing domain web lainnya. Dari hasil kode di java script untuk domain terdapat pembeda id untuk masing-masing web. uinjkt.ac.id memiliki id: 6bf4e7397b2914f6479b56b7bbd1432d.

\begin{tabular}{l} 
var owa_baseUrl = 'http://103.229.202.50/log/'; \\
var owa_cmds = owa_cmds $\|[] ;$ \\
owa_cmds.push(['setSiteId', \\
'6bf4e7397b2914f6479b56b7bbdl432d']); \\
\hline Owa_baseurl merujuk ke ip 103.229.202.50 \\
Dan set id 6bf4e7397b2914f6479b56b7bbd1432d
\end{tabular}

Untuk akademik.uinjkt.ac.id diberikan id: fad1d111c9e8941f08ba29233007a0fe.

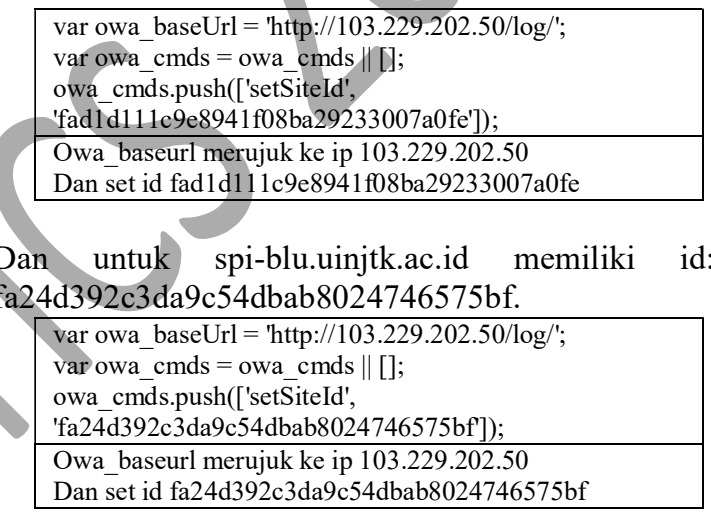

\section{PENGUJIAN}

Implementasi diterapkan di server dengan alamat 103.229.202.50/log. Gambar 1 adalah tampilan login atau halaman awal untuk aplikasi.

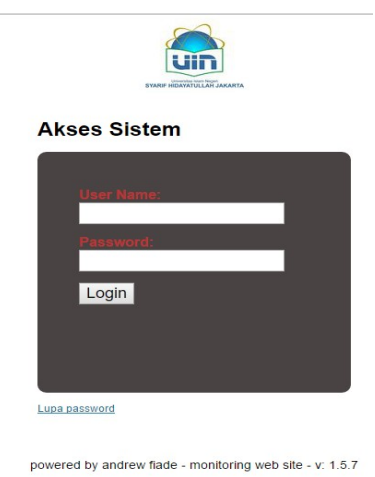

Gambar 1. Tampilan Awal Aplikasi

Dari tampilan Gambar 1 adalah login akses ke sistem aplikasi, diperlukan username dan password untuk 
masuk ke aplikasi. Beberapa site sub domain yang telah berhasil diletakkan di aplikasi, saat ini yaitu:

- psga.uinjkt.ac.id

- ushuluddin.uinjkt.ac.id

- fkik.uinjkt.ac.id

- fst.uinjkt.ac.id

- uinjkt.ac.id

- akademik.uinjkt.ac.id

- feb.uinjkt.ac.id

- psikologi.uinjkt.ac.id

- spi-blu.uinjkt.ac.id

- fitk.uinjkt.ac.id

- uptlab.uinjkt.ac.id

- fidkom.uinjkt.ac.id

- bpi.fidkom.uinjkt.ac.id

- fdi.uinjkt.ac.id

Tampilan screen shoot yang sudah di-set terdapat pada Gambar 2.

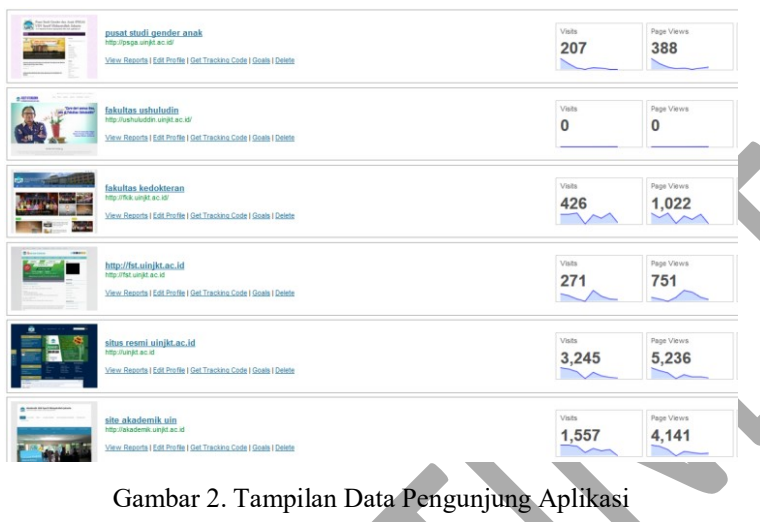

Dari Gambar 2 dapat dijelaskan:

- Situs psga.uinjtk.ac.id telah diakses 207 kali (halaman unik untuk satu pengunjung) dan telah dilihat page view sebanyak 388 kali, artinya halaman yang sama diakses berkali kali dihitung juga oleh sistem.

- Fakultas Ushuludin masih 0, dikarenakan belum berhasil konfig ke web tersebut.

- Peneliti rangkum kedalam sebuah tabel (data terbaru: 11 nov 2015)

Situs Uinjkt.ac.id merupakan situs utama yang diakses dari luar, site uinjkt.ac.id, merupakan gerbang akses ke seluruh informasi sub domain uinjkt.ac.id. Maka situs ini paling banyak diakses dari publik. Dan sering menjadi target dari para user/hacker diluar untuk mencoba meretas site uinjkt.ac.id. Dari aplikasi yang diterapkan terdapat beberapa percobaan yang dapat dilihat di akses aplikasi dalam penelitian ini [7],
Di awal penerapan implementasi aplikasi ini dimulai pertengahan juli, dan site uinjkt.ac.id. Diterapkan dalam aplikasi dan terdapat beberapa halaman yang ingin diakses namun tidak ditemukan. Halaman yang dicoba adalah standar untuk pengaksesan ke login admin, atau percobaan celah teknik sql injection. Untuk bulan juli 2015, halaman yang telah ditest adalah pada Tabel 1 .

TABEL 1. HASIL AKSES uinjkt.ac.id JULI 2015

\begin{tabular}{|c|c|c|c|}
\hline No & $\begin{array}{c}\text { Halaman } \\
\text { yang Diakses }\end{array}$ & 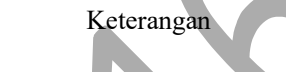 & Iasil \\
\hline 1 & $\begin{array}{l}\text { uinjkt.ac.id/?lang } \\
=. \text {.etc/passwd }\end{array}$ & $\begin{array}{l}\text { User mencoba akses file } \\
\text { letc/passwd untuk } \\
\text { melihat informasi isi. }\end{array}$ & $\begin{array}{l}\text { Gagal, Tidak } \\
\text { ditemukan }\end{array}$ \\
\hline 2 & $\begin{array}{l}\text { uinjkt.ac.id/?lang } \\
=/ \text { etc/passwd }\end{array}$ & $\begin{array}{l}\text { User mencoba akses file } \\
\text { /etc/passwd untuk } \\
\text { melihat informasi isi. }\end{array}$ & $\begin{array}{l}\text { Gagal, Tidak } \\
\text { ditemukan }\end{array}$ \\
\hline 3 & $\begin{array}{l}\text { uinjkt.ac.id/?page } \\
\mathrm{id}=. \text {././././index.p } \\
\mathrm{h} p\end{array}$ & $\begin{array}{l}\text { User mencari akses file } \\
\text { ke index.php }\end{array}$ & $\begin{array}{l}\text { Gagal, Tidak } \\
\text { ditemukan }\end{array}$ \\
\hline & $\begin{array}{l}\text { uinjkt.ac.id/?pp=9 } \\
999^{\prime}\end{array}$ & $\begin{array}{l}\text { User menguji apakah } \\
\text { web tersebut memiliki } \\
\text { kelemahan sqlinjection }\end{array}$ & $\begin{array}{l}\text { Gagal, Tidak } \\
\text { ditemukan }\end{array}$ \\
\hline
\end{tabular}

Diatas adalah percobaan untuk mendapatkan akses informasi user dan password dan index.php serta percobaan sql injection 9999. Namun dari segi keamanan celah tersebut telah ditutupi. Jadi tidak dapat terpenuhi. Tabel 2 berisi analisa hasil akses dari web.

TABEL 2. ANALISA HASIL AKSES uinjkt.ac.id AGUSTUS 2015

\begin{tabular}{|l|l|l|l|}
\hline No & $\begin{array}{l}\text { Halaman Web } \\
\text { yang Diakses }\end{array}$ & \multicolumn{1}{|c|}{ Keterangan } & Hasil \\
\hline 1 & $\begin{array}{l}\text { uinjkt.ac.id/id/ } \\
\text { wp-admin }\end{array}$ & $\begin{array}{l}\text { user mencoba akses } \\
\text { halaman tersebut, untuk } \\
\text { mencari login admin dari } \\
\text { situs uinjkt.ac.id, user } \\
\text { mencoba admin untuk } \\
\text { wordpress }\end{array}$ & $\begin{array}{l}\text { Gagal, Tidak } \\
\text { ditemukan }\end{array}$ \\
\hline 2 & $\begin{array}{l}\text { uinjkt.ac.id/ad } \\
\text { ministrator/ }\end{array}$ & $\begin{array}{l}\text { user mencoba akses } \\
\text { halaman tersebut, untuk } \\
\text { mencari login admin dari } \\
\text { situs uinjkt, user mencoba } \\
\text { admin untuk joomla }\end{array}$ & Gagal, Tidak \\
ditemukan \\
\hline 3 & $\begin{array}{l}\text { uinjkt.ac.id/cpa } \\
\text { nel }\end{array}$ & $\begin{array}{l}\text { user mencoba akses } \\
\text { halaman tersebut, untuk } \\
\text { mencari login admin dari } \\
\text { situs uinjkt, user mencoba } \\
\text { admin untuk control panel }\end{array}$ & $\begin{array}{l}\text { Gagal, Tidak } \\
\text { ditemukan }\end{array}$ \\
\hline
\end{tabular}




\begin{tabular}{|c|c|c|c|}
\hline 4 & $\begin{array}{l}\text { uinjkt.ac.id/id/ } \\
\text { wp-login.php }\end{array}$ & $\begin{array}{l}\text { user mencoba akses } \\
\text { halaman tersebut, untuk } \\
\text { mencari login admin dari } \\
\text { situs uinjkt, user mencoba } \\
\text { admin untuk wordpress }\end{array}$ & $\begin{array}{l}\text { Gagal, Tidak } \\
\text { ditemukan }\end{array}$ \\
\hline 5 & $\begin{array}{l}\text { uinjkt.ac.id/mai } \\
1\end{array}$ & $\begin{array}{l}\text { user mencoba akses } \\
\text { halaman tersebut, untuk } \\
\text { mencari login admin dari } \\
\text { situs uinjkt, user mencoba } \\
\text { admin untuk mail server }\end{array}$ & $\begin{array}{l}\text { Gagal, Tidak } \\
\text { ditemukan }\end{array}$ \\
\hline 6 & $\begin{array}{l}\text { uinjkt.ac.id/skp } \\
\text { o/login.zul }\end{array}$ & $\begin{array}{l}\text { user mencoba akses } \\
\text { halaman tersebut, untuk } \\
\text { mencari login admin dari } \\
\text { situs uinjkt, user mencoba } \\
\text { admin untuk login ais }\end{array}$ & $\begin{array}{l}\text { Gagal, Tidak } \\
\text { ditemukan }\end{array}$ \\
\hline 7 & $\begin{array}{l}\text { uinjkt.ac.id/sup } \\
\text { erphp }\end{array}$ & $\begin{array}{l}\text { user mencoba akses } \\
\text { halaman tersebut, untuk } \\
\text { mencari login admin dari } \\
\text { situs uinjk. }\end{array}$ & $\begin{array}{l}\text { Gagal, Tidak } \\
\text { ditemukan }\end{array}$ \\
\hline 8 & $\begin{array}{l}\text { uinjkt.ac.id/ad } \\
\text { min/admin_log } \\
\text { in.php }\end{array}$ & $\begin{array}{l}\text { user mencoba akses } \\
\text { halaman tersebut, untuk } \\
\text { mencari login admin dari } \\
\text { situs uinjkt. }\end{array}$ & $\begin{array}{l}\text { Gagal, Tidak } \\
\text { ditemukan }\end{array}$ \\
\hline 9 & $\begin{array}{l}\text { uinjkt.ac.id/we } \\
\text { bmaster.asp }\end{array}$ & $\begin{array}{l}\text { user mencoba akses } \\
\text { halaman tersebut, untuk } \\
\text { mencari login admin dari } \\
\text { situs uinjkt. }\end{array}$ & $\begin{array}{l}\text { Gagal, } \\
\text { ditemul }\end{array}$ \\
\hline 10 & $\begin{array}{l}\text { uinjkt.ac.id/ind } \\
\text { ex/index// }\end{array}$ & $\begin{array}{l}\text { user mencoba akses } \\
\text { halaman tersebut, untuk } \\
\text { mencari login admin dari } \\
\text { situs uinjkt. }\end{array}$ & \\
\hline
\end{tabular}

Namun user/hacker tidak menemukan halaman tersebut. Link tersebut tidak ada dalam 3 bulan. Situs uinjkt.ac.id paling sering dilakukan pengetesan oleh user luar. Dalam penelitian ini di-monitoring pengaksesan dan dapat dilihat cara user luar mencoba memasuki server luar. Contoh tampilannya ada di Gambar 3.

Dari penelitian ini didapatkan pula informasi dari negara user yang mengakses situs uinjkt.ac.id. Berikut ini ditampilkan informasi asal negara untuk bulan september. Dari Tabel 3 dapat dilihat akses negara dan berapa kali akses ke site uinjkt.ac.id, dari 5 teratas Indonesia, Australia, Perancis, Amerika Serikat dan Jepang yang sering mengakses. Akses unik artinya satu user mengakses site uinjkt.ac.id, tapi tidak diperhitungkan jika mengakses halaman berkali-kali.

Dapat dilihat bahwa situs UIN selain dari indonesia, diakses pula oleh negara internasional seperti Australia, Perancis, Amerika Serikat dan lain lain. Hasil not set menunjukkan aplikasi tidak dapat membaca informasi negara. Ada kemungkinan user menggunakan proxy sehingga tidak terindentifikasi.

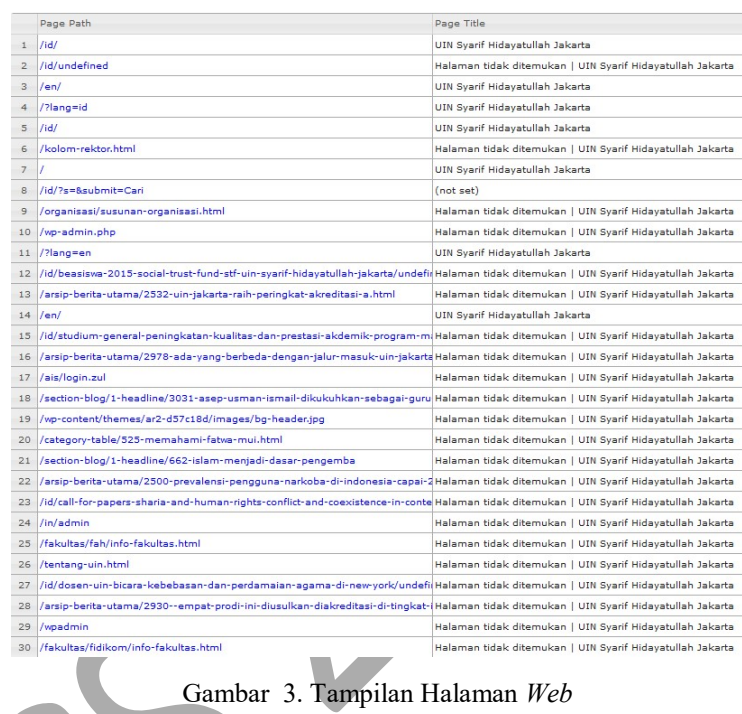

TABEL 3. AKSES NEGARA YANG AKSES uinjkt.ac.id SEPTEMBER 2015

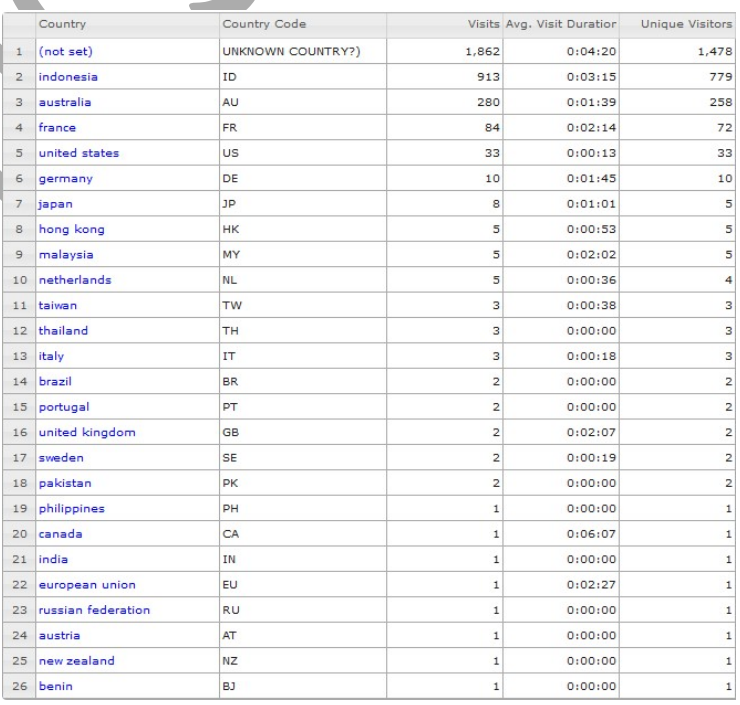

Aplikasi dapat pula menampilkan informasi tipe browser yang digunakan dan jumlah penggunaan untuk browser tersebut. Dari Tabel 4, user mengakses teratas menggunakan $\mathrm{PC} /$ laptop karena browser firefox dan chrome (posisi paling atas). Untuk digunakan di PC/laptop. Akses mobile di urutan ketiga yaitu opera mini, UC browser, dan chrome mobile. Artinya data ini dapat digunakan sebagai data statistik penggunaan browser yang terpopuler saat ini ada $\mathrm{d} i$ firefox dan chrome dan untuk web mobile $\mathrm{di}$ handphone user menggunakan chrome mobile. 
TABEL 4. INFORMASI TIPE BROWSER uinjkt.ac.id SEPTEMBER 2015

\begin{tabular}{|r|r|r|r|r|}
\hline \hline & Browser Type & Visits Avg. Visit Duratior & Unique Visitors \\
\hline 1 & Firefox & 1,401 & $0: 06: 15$ & 1,095 \\
\hline 2 & Chrome & 1,363 & $0: 01: 46$ & 1,131 \\
\hline 3 & Opera Mini & 114 & $0: 00: 33$ & 107 \\
\hline 4 & UC Browser & 103 & $0: 00: 56$ & 97 \\
\hline 5 & Chrome Mobile & 58 & $0: 02: 09$ & 49 \\
\hline 6 & Android & 56 & $0: 01: 55$ & 42 \\
\hline 7 & IE & 30 & $0: 01: 03$ & 29 \\
\hline 8 & Other & 30 & $0: 02: 14$ & 24 \\
\hline 9 & Safari & 28 & $0: 00: 52$ & 16 \\
\hline 10 & Mobile Safari & 21 & $0: 01: 31$ & 19 \\
\hline 11 & Chromium & 6 & $0: 02: 37$ & 5 \\
\hline 12 & ElackBerry Webkit & 5 & $0: 03: 05$ & 4 \\
\hline 13 & BingPreview & 3 & $0: 00: 00$ & 3 \\
\hline 14 & Chrome Mobile iOS & 2 & $0: 00: 00$ & 1 \\
\hline 15 & Iceweasel & 2 & $0: 03: 06$ & 1 \\
\hline 16 & Opera & 2 & $0: 00: 00$ & 2 \\
\hline 17 & Maxthon & 2 & $0: 00: 23$ & 2 \\
\hline 18 & Firefox Beta & 2 & $0: 00: 00$ & 1 \\
\hline 19 & Nokia Services (WAP) Browser & 1 & $0: 00: 00$ & 1 \\
\hline 20 & Yandex Browser & 1 & $0: 00: 00$ & 1 \\
\hline 21 & Opera Mobile & 1 & $0: 00: 00$ & 1 \\
\hline 22 & aBrowser & 1 & $0: 00: 00$ & 1 \\
\hline 23 & Firefox Mobile & 1 & $0: 00: 00$ & 1 \\
\hline & & & & \\
\hline
\end{tabular}

Dalam penelitian ini didapatkan pula informasi alamat ISP yang digunakan oleh user, terlihat pada Tabel 4. Informasi ini digunakan untuk mengetahui ISP yang sering mengakses situs uinjkt, apakah user menggunakan internet melalui handphone, atau lainnya. Dapat dilihat pada posisi nomor dua, user menggunakan akses three.co.id, blackbery.net, Dimana ISP tersebut merupakan ISP Mobile.

Penelitian ini dapat menampilkan informasi tipe sistem operasi yang digunakan oleh user, dalam mengakses web uinjkt.ac.id. Dalam penelitian ini ditampilkan bulan september 2015. Hal ini dapat dilihat pada Tabel 5. Dari informasi tersebut, didapatkan sistem operasi yang digunakan umumnya menggunakan sistem operasi windows.

TABEL 4. ISP ASAL AKSES uinjkt.ac.id SEPTEMBER 2015

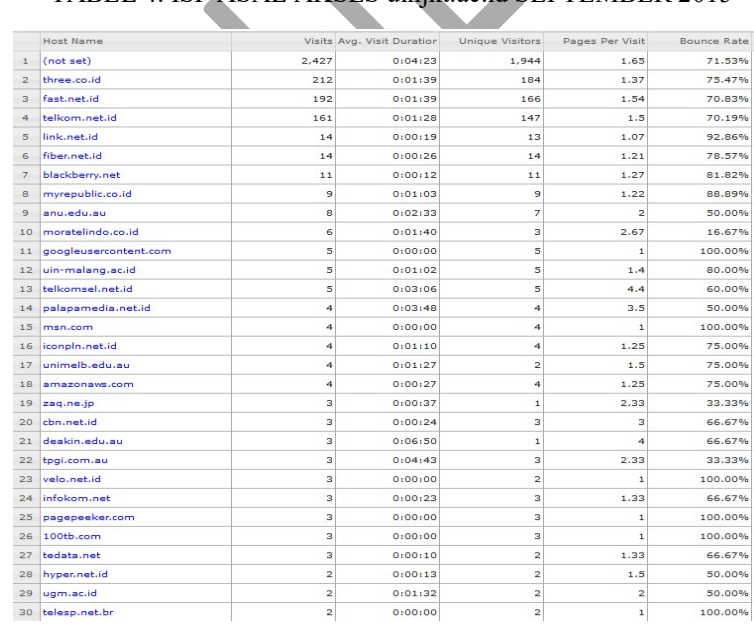

TABEL 5. SISTEM OPERASI YANG DIGUNAKAN uinjkt.ac.id SEPTEMBER 2015

\begin{tabular}{|r|l|r|r|r|}
\hline & Operating System & Visits Avg. Visit Duratior & Unique Visitors \\
\hline 1 & Windovs 7 & 1,596 & $0: 02: 53$ & 1,279 \\
\hline 2 & Windovs & 501 & $0: 02: 07$ & 394 \\
\hline 3 & Windovs XP & 369 & $0: 02: 18$ & 310 \\
\hline 4 & Android & 254 & $0: 01: 26$ & 207 \\
\hline 5 & Windovs 8 & 215 & $0: 01: 34$ & 180 \\
\hline 6 & Other & 128 & $0: 01: 02$ & 122 \\
\hline 7 & Mac OS X & 68 & $0: 00: 55$ & 46 \\
\hline 8 & Linux & 31 & $0: 00: 31$ & 30 \\
\hline 9 & OOS & 23 & $0: 01: 23$ & 20 \\
\hline 10 & BlackBerry OS & 19 & $0: 00: 51$ & 18 \\
\hline 11 & Windows Vista & 12 & $0: 01: 42$ & 11 \\
\hline 12 & Ubuntu & 11 & $0: 01: 30$ & 10 \\
\hline 13 & Solaris & 2 & $0: 11: 00$ & 2 \\
\hline 14 & Symbian OS & 2 & $0: 00: 00$ & 2 \\
\hline 15 & Windows 2000 & 1 & $22: 44: 09$ & 1 \\
\hline 16 & MeeGo & 1 & $0: 00: 00$ & 1 \\
\hline & & & & \\
\hline
\end{tabular}

Saat pengumuman SPMB mandiri UIN, tanggal 1 Agustus 2015, dapat dilihat jumlah akses per user pada Gambar 4.

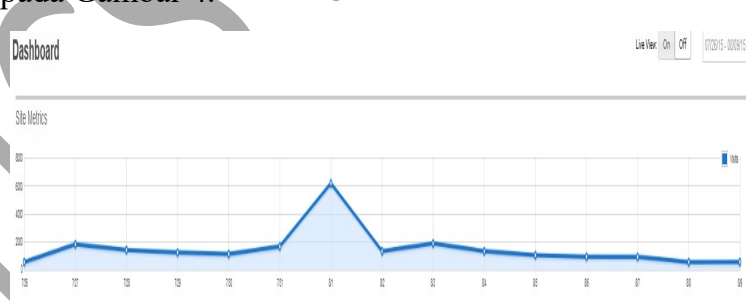

Gambar 4. Traffic Situs Uinjkt.Ac.Id Agustus 2015

Dipilih agustus 2015, karena tanggal tersebut merupakan pengumuman kelulusan SPMB, sehingga traffic uinjkt.ac.id akan diakses oleh banyak peserta SPMB. Dapat dilihat pada tabel jumlah pengunjungnya, per hari dan per pengunjung. Dapat dilihat jika saat mendekati pengumuman trafic mencapai puncaknya di tanggal 1 Agustus 2015 mencapai 6.181 pengunjung. Artinya dari beban server sudah disiapkan untuk traffic di waktu yang penting .

Dari hasil pengujian, situs uinjkt.ac.id mewakili keseluruhan data yang ditampillkan untuk seluruh sub domain situs uinjkt.ac.id. Fungsi dianggap sama karena uinjkt.ac.id lebih banyak diakses dari pengunjung user uinjkt.ac.id dan user luar. Dari hasil percobaan telah didapatkan bahwa fungsi melihat jumlah pengunjung, asal negara, asal ISP telah berhasil. Data dalam statistik pengunjung telah berhasil. Web yang di-input di sistem telah berhasil pula untuk dimonitor ke aplikasi. 


\section{KESIMPULAN}

1. Aplikasi dapat memonitoring situs-situs yang telah dikonfigurasi dengan domain uinjkt.ac.id dan subdomain uinjkt.ac.id. Hasil pengujian situs pengunjung dapat dilihat dalam sebuah statistik.

2. Hasil pengujian menunjukkan halaman web yang sering dikunjungi dapat tercatat pula dengan url lengkap. Hal ini dapat memberikan informasi ke admin, ada tidaknya halaman web yang bersifat merusak. Jika sebuah web telah di-deface oleh penyerang, umumnya intruder tersebut malapetaka file script untuk di-remote. Dengan adanya aplikasi ini, halaman web dapat terpantau untuk setiap URL [8].

3. Aplikasi ini dapat digunakan sebagai data untuk strategi dalam meningkatkan tingkat kepopuleran web, seperti halaman web apa yang sering diakses. Dari hal tersebut dapat diketahui topik apa yang paling banyak diakses oleh user [9].

Implikasi dalam penelitian ini adalah:

1. Admin atau stakeholder memiliki aplikasi monitoring web untuk memantau seluruh web dengan cara mendaftarkan ke aplikasi. [9]

2. Memudahkan admin dalam mengelola web dan melaporkan perkembangan web dalam hal pengunjung akses.

Rekomendasi dalam penelitian ini adalah:

1. Aplikasi ini dapat diterapkan untuk dijadikan salah satu aplikasi monitoring web

2. Aplikasi ini diperlukan pengembangan terutama untuk alert. Seperti adanya alert jika pengunjung lebih dari 1000 per hari. Hal ini untuk memastikan apakah akses web tersebut menajadi lama atau tidak.

3. Penambahan alert jika ada halaman web mengakses percobaan untuk hacking atau script yang aneh, misalkan ada string indikasi /etc/passwd, sql injection, akses admin

4. Seluruh aplikasi web uinjkt.ac.id dapat tersimpan di aplikasi penelitian ini.

\section{REFERENSI}

[1] Badrish Chandramouli, Jonathan Goldstein, Songyun Duan,Temporal Analytics on Big Data for Web Advertising, 2012 IEEE 28th International Conference on Data Engineering

[2] R. Barga et al. Consistent streaming through time: A vision for event stream processing. In CIDR, 2007.

[3] Manish Godse,Rajendra Sonar,Shrikant Mulik,Web Service Selection based on Analytical Network Process Approach,2011 IEEE Asia-Pasific Servicees Computing Conference,978-0-7695-3473-2/08 \$25.00 (C) 2008 IEEE

[4] M. Balazinska et al. Fault-tolerance in the borealis distributed stream processing system. In SIGMOD, 2005.

[5] B. Chandramouli et al. Temporal analytics on big data for web advertising. Technical report, Microsoft Research (MSR-TR2011-87). http://research.microsoft.com/apps/pubs/? id=150002.

[6] Shhwu min Horg, Analysis of Users' Behavior on Web 2.0 Social Network Sites: An Empirical Study, 2010 Seventh International Conference on Information Technology

[7] Kristin Glass, Richard Colbaugh, Web Analyticis for Security Information, 2011 European Intelligence and Security Informaties Conference,978-0-7695-4406-9/11 \$26.00 (C) 2011 IEEE, 978-0-7695-3984-3/10 \$26.00 (C) 2010 IEEE

[8] R. Chaiken et al. SCOPE: easy and efficient parallel processing of massive data sets. PVLDB, 1(2), 2008

[9] Y. Chen, D. Pavlov, and J. Canny. Large-scale behavioral targeting. In KDD, 2009.T. Condie et al. Mapreduce online. In NSDI, 2010.10] A. Das et al. Google news personalization: Scalable online collaborative 